\title{
Exploring the Impact of Cultural Values on Project Performance
}

- The effects of cultural values, age and gender on the perceived importance of

project success/failure factors.

Maxwell Chipulu

University of Southampton, United Kingdom

(m.chipulu@soton.ac.uk)

Udechukwu Ojiako

University of Johannesburg, South Africa

(uojiako@yahoo.ca)

Paul Gardiner

The British University in Dubai, United Arab Emirates

(paul.gardiner@buid.ac.ae)

Terry Williams

University of Hull, United Kingdom

(terry.williams@hull.ac.uk)

Caroline Mota

Universidade Federal de Pernambuco, Brasil

(carol3m@gmail.com)

Stuart Maguire

University of Sheffield, United Kingdom

(s.maguire@sheffield.ac.uk)

Yongyi Shou

Zhejiang University, China

(yshou@zju.edu.cn)

Teta Stamati

University of Athens

(teta@di.uoa.gr)

Alasdair Marshall

University of Southampton, United Kingdom

(A.Marshall@soton.ac.uk 


\section{Abstract}

Purpose- This study explores the impact of cultural values on the importance individuals assign to project success/failure factors.

Design/methodology/approach-Themes emerging from 40 interviews of project practitioners based in Brazil, China, Greece, Nigeria, Thailand, the United Arab Emirates, the United Kingdom and the United States are integrated with literature evidence to design a survey instrument. 1313 practitioner survey responses from the eight countries are analysed using multi-group, structural equation modelling.

Findings - Ten project success/failure indicators (PSF/s) are found to reduce to two main project success/failure factors (PSFFs): (1) project control and extra-organisational goals, and (2) project team management/development and intra-organisational goals. It is found that the levels of importance individuals assign to both factors are dependent, not only on age and gender, but also on cultural values measured as constructs based on Hofstede's individualism, masculinity, power distance and uncertainty avoidance dimensions.

Research limitations - The snowballing method used to gather survey data and analysis of relationships at individual level reduce generalisability.

Practical implications - The results reveal insights on how best to match the cultural values of project participants to project characteristics. They also increase knowledge on the likely perceptual differences among culturally-diverse individuals within projects.

Originality/value - This research contributes to the literature on culture in project environments by defining a factor structure of multiple-dependent project success/failure indicators and increases insight on how specific cultural values may impact on the perception of the so-defined project success/failure factors. 
Keywords: project management, cultural values, Hofstede dimensions, project success, project failure.

\section{Introduction: Culture in projects}

In a project, for a finite period of time, human and other resources are pooled to conduct a diverse set of activities to achieve a one-off, unique set of objectives. Projects are important in organisations. Where products or services are bespoke or partially so, such as in management consulting and software development, project-production forms the core of the value-adding activities of the firm (Hobday, 2000, Scott-Young and Samson, 2008). In manufacturing, firms recurrently run projects to develop products (Pasche et al., 2011). More generally, firms may engage in capital investment projects (Bryde, 2003). They must also occasionally conduct strategic initiatives, which can face very similar challenges to projects: both contexts can be unstructured and novel; 'scoping' issues can require careful consideration; and collective decision making processes may well give regard to multiple inter-dependent criteria. Within project teams, individual team members require skills such as formal planning (Scott-Young and Samson, 2008, Bendoly et al., 2010); the ability to utilise matrix and dynamic team structures (Mendez, 2003) which facilitate flexible learning (Bresnen et al., 2004). These skills, too, can help support the delivery of strategic initiatives. It has been argued, thus, that a firm's capability to manage projects successfully could be critical to the success of strategic initiatives (Pinto and Kharbanda, 1995).

Project environments are, however, characterised by levels of complexity and uncertainty that create difficulties in identifying project success/failure factors (PSFFs). In an ideal world, project success or failure could be measured by assessing how closely the project achieved intended outcomes once it had been decommissioned. In the real world, 
decision makers have to define PSFFs up front to evaluate projects for selection and thereafter to monitor progress and evaluate performance. Obviously, the selection and, subsequently, the evaluation of PSFFs are critical. Where previously the view was that project success could be measured using easily quantifiable metrics based on cost, time and quality (Rubin and Seeling, 1967), it is now generally accepted that measures of success or failure should go beyond this triangle (Thomas and Fernández, 2008); should be dynamic and flexible (Shenhar et al., 2001); and should incorporate the perspectives of different stakeholders (Fowler and Walsh, 1999). But perceptions of PSFFs are likely to vary subjectively between different stakeholders (Pereira et al., 2008) and could, additionally, vary over the life-cycle of the project (Pinto and Prescott, 1988). Hence both individuallyand culturally-primed perceptions are key in the identification and assessment of PSFFs.

Nisbett and Miyamoto (2005) have recently reported that, over and above age and gender, individual perceptions can vary strongly with cultural differences. Given that PSFFs are subject to perceptual differences, which are in turn subject to cultural differences, it follows that in modern projects, characterised by highly social configurations(Bendoly et al., 2010), PSFF perceptions among project participants might vary for reasons that are researchable through the use of instruments that tap cultural differences. As organisations attempt to recruit from a wider talent pool and/or accrue cost savings, multi-cultural project teams become ever more likely. To succeed, it is necessary that the participants in multicultural projects understand cultural differences and what those differences imply. Many of the factors that have been identified as significant causes of project failure could be culture-dependent: use of inappropriate team structures (Hobday, 2000); inability to sustain stakeholder confidence and interest (Chen et al., 2009); volatility in project team dynamics (Gelbard and Carmeli, 2009); poor team integration (Scott-Young and Samson, 
2008); cultural readiness(Motwani et al., 2002); and ineffective communication (Jugdev and Müller, 2005). In fact, the intercultural effectiveness of individual project team members can affect the overall performance of multicultural project teams (Symkhovych, 2009), which may explain the frequent demand by industry for project managers competent in multicultural interactions (Chipulu et al., forthcoming) .

A review of the current literature suggests culture can affect projects in several ways. First, at a fundamental level, cultural differences can increase team heterogeneity. This can have benign consequences. If managed properly, heterogeneous project teams (e.g. by culture, gender, ethnicity) can perform substantially better than homogenous teams (Miller et al., 2000). They are, for example, more likely to search for and find innovative, nonconventional solutions in novel or challenging situations. Conversely, homogeneity improves communication, particularly of the non-verbal kind. Hence if culturally-diverse teams are not properly managed, poor communication (Loosemore and Lee, 2002) can result. Second, given the one-off, unique nature of projects, success to a large extent depends on the effective learning and development of the project team members. There is plenty of evidence from pedagogical studies to suggest that people of different cultures tend to have different preferred learning styles (Ramburuth and Mccormick, 2001). Hence, culturally dissimilar project team members may prefer to learn, scan their environments, or perhaps identify risk, in contrasting ways. Some authors go as far as to say that cross-cultural training fails to adequately address the organisational and environmental factors that impact significantly on the overall success of international projects (Kealey et al., 2005). Moreover, it may well be that feedback, a critical learning mechanism in projects, ought to be given more often in a culturally-sensitive manner if it is to be effective (Chevrier, 2003). Similarly, culturally divergent team members may respond best not only to different work models 
(Cagliano et al., 2011), but also to differing styles of project leadership (Wiengarten et al., 2011): some preferring directive leadership, others favouring a collaborative, participatory style (Harris, 2004). Culturally diverse project teams may, additionally, be affected as a result of having conflicting views of project planning (Zwikael and Ahn, 2011), the importance of the individual over the team (Varnum et al., 2010), the importance of 'masculine' over 'feminine' qualities (Henderson and Stackman, 2010) and differences in perceptions of risky outcomes (Weber and Hsee, 1998).

Clearly, culture matters in projects, particularly, as it does, more generally, in operations management (Pagell et al., 2005). Yet there are some limitations in the literature within these domains. First, though numerous studies have examined how organisational culture impacts on the performance of operations, there has not been parallel research focused on projects within operational environments despite, as we have argued above, the importance of projects in operations and organisations in general. Specifically, there has not been a full exploration of the impact of cultural values on the perception of project success/failure factors (PSFFs). Second, some scholars, such as Childe (2011), looking to set the agenda for operations management research, overlook culture, even though the operational environment is social in nature. Third, as the critiques of Prasad and Babbar (2000), and Pagell et al. (2005) both highlight; the majority of international operations studies do not analyse international differences from the cultural perspective. Instead, they rely on differences observed between countries or geographical regions. To help address these issues, we pose the following research question: To what extent do cultural values impact on the importance attached to project success/failure factors? The rationale is simple: The importance attached to project success/failure factors affects project performance. If key success/failure factors are, somehow, perceived unimportant and, consequently, are 
overlooked; performance will suffer. Therefore, greater insight on the likely effects of cultural values on the perception of these factors could lead to improved project performance and subsequently organisational performance.

By definition, projects are temporary and relatively short-term in nature so that it may not be possible for project-team members and other stakeholders, coming from diverse organisations themselves, to develop a prevailing culture at the collective project level. Therefore, within project environments, if significant cultural value differences do exist, they are likely to persist for the duration of the project and their impact on performance may be much greater than within the wider organisation (of the project participants) where the effect of the extant organisational culture could be more significant. Thus, we argue that our research question could uncover further insights beyond extant research on the impact of culture on organisational behaviour and operations management such as, for instance, that put forward by Prajogo and Mcdermott (2011); and Burnes and James (1995).

The structure of the rest of this paper is as follows: Next, we describe the study, summarising the methods and data used. In section three, we report the results. In the final section, we discuss the implications of the results and suggestions for future research.

\section{The study}

We used mixed research methods in the four stages described below.

\section{$\underline{2.1}$ 'Culture' and Cultural Difference Measures}

'Culture' can be at once tangible and observable; latent and unobservable; or even an abstraction altogether. Unsurprisingly, then, there exist varying paradigms within which 
culture may be explored. Within management and organisation studies, perhaps the most influential cultural perspective has been that of Hofstede (Søndergaard, 1994). Based on a very large sample of IBM employees, Hofstede (1980; 1983b) initially posited the existence of a 'national culture' which could be measured along four dimensions: power distance, individualism/collectivism, masculinity/femininity and uncertainty avoidance/preference. Later, Hofstede and Bond $(1984 ; 1988)$ added a fifth dimension termed long-term/shortterm orientation.

Hofstede's model has drawn criticisms. Notably, in a scathing critique, McSweeney (2002) questions Hofstede's framing of culture as 'national', the methodological assumptions which underpin the framework and the findings. Winch et al. (1997) tested and rejected hypotheses implied by Hofstede (1980) on the effect of cultural dimensions on differences in organisational structure between the French and British. Nevertheless, perhaps because it is clear and parsimonious, Hofstede's framework remains influential: A number of studies have found Hofstede dimensions to affect a wide variety of outcomes as main effects, moderators and mediators; as well as at different levels (Kirkman et al., 2006). Applications range from the use of Hofstede's dimensions as a basis for cultural measurement (Newman and Nollen, 1996, Pagell et al., 2005), comparators for alternative dimensions (Schwartz, 1994b) or part-basis for a new framework (House et al. 2004, p. 13). Thus, while mindful of the shortcomings of Hofstede's framework, we adopted it to explore how cultural values may impact on project success/failure factors. We excluded the fifth dimension from our study because, compared to the original four dimensions, it has earned much less acceptance and application (Fang, 2003) and as such remains (relatively) untested. This may be due to doubts that it truly represents a long-term orientation. Originally labelled 'Confucian Work Dynamism', Hofstede re-labelled the dimension following studies 
that showed it significantly correlated with indicators of long-term orientation. However, not only do equally plausible alternative explanations exist for why those (supposed) indicators of long-term orientation co-vary with 'Confucian Work Dynamism' but it is also argued that some items on 'Confucian Work Dynamism' are incompatible with a 'long-term orientation' (House et al. 2004, pp. 286-289).

Hofstede's dimensions were derived from country-level data and he cautions against using them at other levels of analysis (Hofstede, 1980, Hofstede, 2001). Going against this caveat, in this paper we will study individual cultural values measured as psychometric constructs based on Hofstede's dimensions. Our approach represents a significant departure from Hofstede's original framework, which, as a reviewer pointed out, should be discussed fully. Our reasons for taking the individual-level approach were as follows:

First, though Hofstede's framework was not intended for individual level analysis, there are many precedents at this level of application in the literature. Kirkman et al. (2006), who reviewed 64 such studies, state that analysis at the individual level is valid. Further, authoritative, support for the individual level approach can be found inTaras et al. (2010). Second, alongside cultural values, we also wished to explore the effects of individual gender and age differences on PSFFs. Third, there are problems with country-level analysis. To use country as unit of analysis it is not only necessary to have a large sample of countries but also control for the effect of other cultures, namely organisational [e.g. Hofstede's (2001) use of a single organisation]; industrial [e.g. House et al. (2004) use of three industry sectors]; occupational [e.g. Schwartz (1994a) control of professions sampled]. Having only sampled project practitioners, we could claim to have controlled for the occupational but, as we explain below, our data were collected such that neither organisational nor industry 
cultures could be controlled for. Further, and, arguably, more fundamentally: Can it be claimed that, following aggregation, the data measure 'national' cultures? There are those, e.g. Eckhardt (2002) and Mcsweeney (2002); who argue that nations are in themselves too ill-defined, too changeable to be considered unique, stable units of analysis. We find this argument compelling in the light of McSweeney's (2002) examples of post-Hofstede (1980) changes in country borders in Eastern Europe, the re-integration of Hong Kong into Mainland China and so on. There is evidence in some studies, including Hofstede (1980), of cultural heterogeneity within nations (Sivakumar and Nakata, 2001, Lenartowicz and Roth, 1999), some even suggest within-country differences (on some dimensions) could be larger than between-country (Au, 1999). The use of country-means could mask a lot of important within-country variation. Hofstede's dimensions were derived more than thirty years ago. His data are even older. The world has changed since then. One big change has been the scale and number of countries involved in migration, which is now considered an important factor of social (including cultural) transformation in all regions of the world (Castles, 2000). As we report below, a good proportion of project practitioners could be migrants, living and working abroad. In an effort to extract a 'pure' national culture, we could discard data presented by migrants (as Winch et al, 1997 did) but we believe such an approach epistemologically questionable: the migration of project practitioners or other highly skilled persons is unlikely to cease as nations search worldwide to fill skills gaps (Mahroum, 2000). We argue that a sample of project practitioners excluding migrants would be unrepresentative of the populations of practitioners in some countries.

In terms of paradigm, it may appear that studying cultural values at individual level deviates from Hofstede's original definition of culture as 'the collective level of mental programming... common to a group... but different... to other groups' (Hofstede 2001, p. 2), 
which may be construed to imply that culture is observable only at the collective level. However, though cultures may be developed to meet societal needs (Hofstede, 2001, Lenartowicz and Roth, 1999, Schwartz, 1994b), the emergent cultures engender cultural values in individuals (Fernández et al., 1997, Rokeach, 1973, Triandis, 1979). As such, as a result of membership of a collective, an individual may be 'cultured' in so definable a way that $s /$ he has different values to an individual from another collective; and like other psychometric constructs, we can use summated rating scales (e.g. Edwards 1997) to measure his/her latent cultural values by observing the level of his/her beliefs that are indicative of the values of interest.

There are pros and cons to our approach. We cannot directly extrapolate our results to societal level. Doing so would be to commit what Hofstede (2001) refers to as the 'reverse ecological fallacy'. This limits the extant literature that we can use to frame our results as the effects of the cultural values, specifically collectivism-individualism, may vary by level of analysis (Oyserman et al., 2002). We are, on the other hand, able to study the cultural values of individuals irrespective of the causal collectives. We argue that, with respect to project practice, this approach is not just advantageous but unavoidable too because project practitioners may routinely enter (and leave) group after group in their work on different projects. It would be difficult to separate the effects of such group cultures from each other and from wider cultures, such as 'national'. We contend further

that a study of macro (country) level relationships would be less useful to project management practice because it is usually individuals that interact in projects, not countries.

\subsection{Establishing Project Success/Failure Indicators (PSFIs)}


We collected data, principally, from Brazil, China, Greece, Nigeria, Thailand, the United Arab Emirates (UAE), the United Kingdom (UK) and the United States (US). We selected these eight countries based on two intertwined criteria: First, with the exception of China, all eight appeared in Hofstede's original country rankings; with Nigeria under 'West Africa' and the UAE under the 'Arab World'. China was sampled later in Hofstede and Bond's (1988) work on China. Judging from the original country scores on the four dimensions, we were able to infer that data collected from these eight countries would prove heterogeneous between nations. Second, Cavusgil and Das (1997) recommend that to conduct cross-cultural research effectively, the researcher must understand (i) the national culture, (ii) the phenomenon under study and (iii) how the phenomenon may be conceptualised against at least one other culture. Therefore, rather than compromise our research by having our researchers based remotely from each 'foreign' country under study, the eight countries were selected because there was a member of the research team living there who was either a national or long-term resident of the country and could therefore understand its national culture. Each country researcher was also a project management expert who had travelled extensively.

Above, we reported that there are no longer universally accepted measures of project success and or failure. Therefore, the next part of the study was to establish what, according to practitioners based in the selected countries, could be used as appropriate measures of project success or failure. This objective was achieved by interviewing practitioners based in the selected countries. The interviewees were identified and recruited to the study through project management professional networks. All interviews were conducted locally by the researcher based in that country. In total, 40 interviews took place between January and May 2010. Each interview lasted 45 to 60 minutes and was semi- 
structured. Table I shows the framework for the interviews, which was derived from a review of literature on the cultural context of project management (Hofstede, 1983a, Keil et al., 2000, Zwikael et al., 2005). All interviews were conducted in English; except in Brazil, China and Thailand where each interview was conducted in the country's national language (then transcribed and translated into English by the interviewer).

\section{[Table I about here.]}

Following transcription, an independent researcher (i.e. not one of the interviewers) coded the interview transcripts for emergent themes in Nvivo 8. Four themes emerged: determinants of success, assessing success, perception of success and stakeholders' perception. The content of the interviews under each theme was then analysed in detail. From the content analysis of the 'assessing success' theme, we identified ten measures of project success or failure. These (measures) are classed in this paper as project success/failure indicators (PSFIs) from which the research will seek to identify more robust project success/failure factors (PSFFs), as explained in section 2.4. The ten PSFIs (shown in table II) are similar to those identified in previous studies that have examined project success/failure measures. Of particular relevance are Hoegl and Gemuenden (2001) who focussed on team development as a success factor; Pinto and Slevin (1987) who extended

measures of success (beyond the so-called golden triangle of time, cost and quality) to include 'client satisfaction', 'technical validity' and 'organisational effectiveness'; Shenhar et al. (2002) whose model included thirteen indicators, the most distinctive of which (compared to previous models such as Pinto and Slevin, 1987) was the addition of 'commercial success' and 'market share'; and most recently Muller and Turner (2007) and 
Muller et al. ( 2012) whose eight measures are very similar to ours, though they combined time, cost and quality into one indicator.

\section{[Table II about here.]}

\section{$\underline{\text { 2.3 Survey Instrument for Cultural values and Project Success/Failure Indicators }}$}

To enable concurrent data collection of individuals' cultural values and perception of the importance of PSFIs, we designed a survey instrument comprising three sections:

In the first section, data were collected on independent individual characteristics, viz. age, gender and primary project role, i.e. the role with which each respondent had accumulated most experience within project environments. Stull and Von Till (1994) found that, beyond age and gender, individual levels on the four Hofstede dimensions may vary as a result of exposure to other cultures. Therefore, to get an appreciation of the amount of cross-cultural exposure within our sample of respondents, we also collected data on their country of birth, country of residence (i.e. where s/he was living at the time of the survey), the number of languages besides their native language that they could speak fluently, the number of countries other than their birth or residence (if different) they had visited for up to three weeks and also, as a separate item, for longer than three weeks.

In section two, each individual's cultural levels were captured. Instead of Hofstede's original scales, we used items based on Hofstede's (1980) original four dimensions developed by Stull and Von Till (1994). Stull and Von Till tested their items by comparing them with six other scales that measure aspects of culture (including Hofstede's 'HERMES' scale); and, as a result, appear much more reliable than Hofstede's original scales [see, for example, Fernández et al. (1997) for a critique of Hofstede's scales]. The Stull and Von Till scale was developed to measure cultural levels on the four dimensions at the individual 
level. Levels of uncertainty avoidance, power distance, individualism and masculinity are each measured as summated values of 10 sub-items on a bipolar Likert scale. Apart from the reasons discussed in section 2.1 , there are further advantages for adopting this summated rating scale instead of Hofstede's original scales. One is that we were able to analyse the impact of the four cultural value dimensions simultaneously using the same structural equation model (SEM). Such parametric analysis would not have been appropriate had we used Hofstede's original method of calculating power distance scores using categorical data (Winch et al., 1997). Winch et al. (1997) also argue that Hofstede's uncertainty avoidance scale contain a behavioural variable measuring feelings at work rather than cultural values.

In the final section of the survey, respondents were asked to rate on a five-point bipolar Likert scale how important they thought each of the ten PSFIs (in table II) were. To increase the validity of responses, for each PSFI, an example of how 'success' and 'failure' for that PSFI could be determined was given (please see the third and fourth columns in table II).

Once completed, the initial survey was piloted with $47 \mathrm{MBA}$ students at the University of Southampton who were, at the time, taking a module in project management. The pilot sample was selected firstly on the basis of their similarity to the target population: They were experienced managers; most with experience of projects as managers and their study of project management also meant they had a good understanding of project management, particularly factors that may influence success or be used to assess success. The group was also multi-cultural, representing many different nationalities. Secondly, two of the researchers had sufficient access to the pilot sample so that they were able to extensively debrief the pilot respondents about characteristics of the instrument that could 
have led to inaccurate data collection [e.g. Dillman (2007)]. Feedback obtained was used to revise the clarity of the survey items in the third section ${ }^{1}$. The revised survey was redistributed to the same group of MBA students and further fine-tuned as per their subsequent comments. The final survey was administered via two channels: (i) direct distribution by the researchers in each country to practitioners through his/her professional project management networks; and (ii) online through the PMI website. We used a 'snowballing' sampling strategy, whereby each practitioner contacted was asked to distribute the survey to his/her professional network. Though snowballing is a nonprobability sampling technique, it is widely used in a situation such as this where a complete list (sampling frame) of appropriate responders (in this case experienced practitioners) does not exist, such as in Walker and Brammer (2009). The online survey was in English as were all directly distributed surveys, except those directly distributed in Brazil, China, Greece and Thailand: In these four countries, the surveys were first translated into the target languages and then back-translated by different bilingual translators, with identified differences resolved to ensure equivalence.

All survey data were collected between March and December 2011. In total, 1313 practitioners returned the survey. Of the 1313 returns, 58 were discarded because they were incomplete, with missing values in research-critical items (i.e. cultural value items, PSFIs or both), leaving 1255 usable responses. Of these, 64\% were men; 36\% women. Though the typical respondent was aged, on average, 36 years; the respondents' ages varied widely, ranging from 18 to 74 .

\footnotetext{
${ }^{1}$ No revisions were made to the first and second sections of the survey.
} 
The 1255 practitioners lived in 31 different countries, covering all the major continents of the world. The majority of the data (96\%) were collected from people living in the eight countries selected for the study (see table III). Comparison of the country of birth and country of residence at the time of the data collection suggests that, overall; just over $22 \%$ of the respondents were not living in their country of birth at the time of the data collection. Thus, the number of birth-countries of the respondents was much greater (62), leading to a wider spread globally. Closer examination of the percentage of people that were living in their country of birth at the time of the study reveals differences among the countries: almost all (at least 95\%) of the respondents in Brazil, China, Greece, Nigeria and Thailand were nationals of those countries. In contrast, $28 \%, 24 \%$ and $69 \%$ of respondents in the UK, the US and UAE, respectively, were born elsewhere. About two in three (66\%) respondents had made at least one short (up to three weeks) visit to another country besides their birth or current country of residence; $44 \%$ had made at least one longer visit of over three weeks. Additionally, most (79.4\%) of the respondents were at least bilingual. It appears, then, that many respondents had either brief or long-term exposure (or both) to other national cultures beyond their own; some indirectly (e.g. by learning a foreign language) and others directly through foreign visits or residencies. It might therefore be untenable to suppose that, within our sample, there exists a 'pure' national culture within each country, especially in countries with a large expatriate community such as the UAE.

Acceptable Cronbach alpha values were found for all four culture value dimensions based on Hofstede (also shown in table III). So the ten sub-items under each dimension were summated into a single scale. In table III, the standardised values of each country's mean (vis-a-vis the sample mean and sample standard deviation) on the four dimensions are shown. It can be observed that none of the countries exhibit unusually high (or low) values 
on all four dimensions. The UAE, the US and Brazil appear to have the strongest levels; whereas Thailand, Nigeria and the UK appear to have weak levels on all four dimensions. The remaining countries have mixed levels.

\section{[Table III about here.]}

As shown in table IV, there were altogether ten frequently occurring primary project roles. It can be seen that the majority of the respondents (87\%) had gained at least some experience of project management environments; a fair proportion (52\%) had hands-on experience as project managers, directors or consultants. We can conclude that most of the respondents are likely to have had experience of assessing some or all of the PSFIs under study; and should be able to not only understand what each PSFI entails but also assign it a meaningful level of importance. Overall, the majority (at least $80 \%$ ) of practitioners considered all ten PSFIs either 'important' or 'very important'.

\section{[Table IV about here]}

\subsection{Structural Equation Modelling of Survey Data}

Finally, to answer the research question, the survey data were analysed using Structural Equation Modeling (SEM) in AMOS 19. We chose SEM because, taking an exploratory approach, it allowed us to examine how the known cultural values may impact on the hitherto unknown factorial structure (based on importance) of PSFIs. We tested three hypotheses simultaneously in the SEM model. The first was the main hypothesis which goes directly to answering the research question: 
H1: There exist variations in the importance individuals assign to PSFFs as a result of differences in levels in the four cultural values: individualism, uncertainty avoidance, masculinity and power distance;

In order to account for the likely influence of both age and gender, we also tested:

H2: There exist differences in the effect of cultural values on how individuals assign importance to PSFFs as a result of age; and

H3: There exist differences in the effect of cultural values on how individuals assign importance to PSFFs as a result of gender.

Unlike the four Hofstede dimensions, there currently exists no research to support or suggest a particular factorial configuration for the importance of PSFIs. Therefore, to explore the factors, if any, which the importance individuals assign to PSFls reduce to, an independent exploratory factor analysis (EFA) was conducted a priori on the ten PSFIs. The results of the EFA were then used to guide the development of the SEM model. EFA is often used in a situation such as this to investigate whether interrelationships exist among a large number of variables (the PSFIs in this case); since if interrelationships do exist, the number of variables can be reduced into a smaller number of more robust factors. Reducing the number of variables reduces complexity, which, it is hoped, helps reveal clearer insights. Similar applications in project management include Muller et al. (2012) who linearly combined project success indicators into one overall success factor; and Shenhar et al. (2002) who examined pre-defined dimensions of success using multivariate methods.

\section{Results}

\subsection{Exploring the Factor Structure of Importance Assigned to PSFIs}


Figure 1 shows the scree plot obtained from the EFA of the ten PSFIs. Based on the widely used Kaiser's rule of retaining only factors with Eigenvalues greater than unity, the first two factors should be retained. The curvature of the scree plot supports this decision. There is a clear, sharp change in gradient (an 'elbow') at factor 2. In moving from factor 1 to 2 , there is significant improvement in the amount of variance explained. After factor 2 , the improvement due to each successive factor diminishes to less than $5 \%$. This suggests the main commonalities in how individuals attach importance to PSFIs are captured by the first two factors, which together explain $53 \%$ of the variance. The other factors account for uniqueness.

\section{[Figure 1 about here]}

To facilitate factorial interpretation, the initial component matrix was rotated using the Varimax criterion. Subsequently, the loadings of the 10 PSFIs on factors 1 and 2 were as shown in table $\mathrm{V}$ below.

\section{[Table V about here.]}

We can observe in table $\mathrm{V}$ the high positive loadings of 'budget', 'risk/safety and communication' and 'time' on factor 1 . Collectively, these high loadings suggest a common 'project control' focus. Simultaneously, the high positive loadings of 'client/sponsor brief', 'project scope' and 'wider society/economy' suggest the impact or effectiveness of a project externally, i.e. beyond the project team and their parent organisation. Hence, in brief summary, this factor appears to combine indicators of project control and extraorganisational goals. To begin to interpret this domain in ways that could hold implications for project management practice, we might say that by conceiving of project success as ' $a$ 
job done to specification, on time and on budget' factor 1 managers seem to emphasise a traditional, task-focussed managerial professionalism.

Turning to factor 2, we observe strong positive loadings for 'leadership and decision making', 'the project team' and 'business/organisational goals'. In brief summary, this factor appears to bring together indicators of project team management/development and intraorganisational goals. Tentatively, and mindful of the possibility that differences between factor 1 managers and factor 2 managers could have ramifications for project management practice, we chose to differentiate this from the first domain by conceiving of it as more people-focussed. Factor 2 managers may be more likely to value their social relations and experiences as project managers - e.g. their direct interactions with project partners and parent organisations - as proxies for project success. Hence whereas factor 1 managers may rely more on formal measures and indicators of project success, factor 2 managers may be more likely to derive insight from less tangible proxies such as perceived levels of social capital or amicable cooperation in project teams. On this interpretation, their greater concern for 'intra-organisational' as opposed to 'extra-organisational' goals may simply reflect their greater concern for how they interact with line management within their parent organisations, as opposed to how they perform on measures that tap into their projects' social and environmental impacts.

Our tentative differentiation, on which further development we defer to our conclusion, seems to be one that project planners, concerned to improve the fit between types of project and managerial skillsets, could find useful. Specifically, factor 2 managers could be better managers of project novelty and ambiguity in circumstances where traditional mechanisms of project control are ineffective. They may find that by scanning 
their social environments for patterns of effective and ineffective co-working, they can outperform factor 1 managers through superior alertness and responsiveness to hard-toanticipate and fast moving project issues.

Based on these results, the initial SEM model was developed with the PSFIs loading on factors 1 and 2, which were project control and extra-organisational goals; and project team management/development and intra-organisational goals, respectively. Of the ten PSFIs, 'quality' has the most ambiguous correlations with the two factors: The absolute difference of its loadings on the two factors (0.354 vs. 0.589$)$ is not as great as those of the other nine PSFIs. We therefore decided to model 'quality' initially as cross-loading on both factors. We note in particular that this variable's stronger loading on factor 2 does not necessarily conflict with our view that factor 2 project managers may be less reliant on traditional measures of project success.

\subsection{Structural Equation Modelling(SEM) Results}

Preliminary analysis showed significant non-normality within the dataset. As such, the SEM model was estimated under asymptotic distribution free (ADF) estimation, which is the appropriate technique when the assumption of multivariate normality is violated (Browne, 1984). To take into account gender effects, the model was run under multi-group analysis, setting gender as the grouping variable. The final SEM model was extracted with a goodness-of-fit index (GFI) of 0.958, adjusted goodness-of-fit index ( $A G F I)$ of 0.929 and root mean square error of approximation (RMSEA) of 0.035 (with a p-value of the RMSEA being close to 0.05 of 1 ). Given these fit statistics, it can be concluded that the final model fitted the data very well (Byrne, 2010). 
The SEM results support all three hypotheses, i.e. cultural values of individualism, masculinity, power distance and uncertainty avoidance impact on the level of importance individuals assign to PSFFs (H1); and that the effects of the cultural values on PSFFs vary with age $(\mathrm{H} 2)$ and gender $(\mathrm{H} 3)$. The relationships between the four cultural values, age and PSFFs were as shown in figures 2 (females) and 3 (males). Except for the coefficient of factor 1 on quality for women, all the path coefficients shown in figures 2 and 3 are statistically significant at least at the $0.05 \mathrm{p}$-value level. We will now report the SEM results in greater detail.

\section{H1: Impact of Cultural values on Importance assigned to PSFFs}

As shown in the path diagrams (figures 2 and 3), both power distance and individualism appear to significantly affect the two PSFFs. This is not so for masculinity and uncertainty avoidance: masculinity only significantly affects factor 1 , uncertainty avoidance only factor 2. As the levels of masculinity and power distance increase, the importance individuals attach to project control and extra-organisational goals is likely to increase. Similarly, it is likely that individuals with higher levels of collectivism ${ }^{2}$ and uncertainty avoidance will assign higher levels of importance to project team/management and intraorganisational goals. In contrast, higher levels of individualism are likely to be associated with higher levels of importance being assigned to project control and extra-organisational goals; and higher levels of power distance are likely to be associated with lower levels of importance being assigned to project team management/development and intraorganisational goals. These results appear intuitively sensible.

\footnotetext{
${ }^{2}$ In this paper, 'individualism' represents values on the individualism-collectivism continuum and were coded such that low scores represent strong individualism and high scores strong collectivism.
} 
Turning to the size of the effects, of the four Hofstede dimensions, the largest differences in the importance individuals (of any gender) assign to project control and extraorganisational goals are likely to coincide with differences in levels of masculinity. In contrast, cultural values that are associated with the greatest differences in importance attached to project team management/development and intra-organisational goals are different for men and women: For women, the largest differences are likely to be observed as a result of variations in individualism, whereas for men it would be uncertainty avoidance.

\section{H2: Impact of Age on Importance assigned to PSFFs}

Age appears to affect the perception of the importance of project control and extraorganisational goals both directly and indirectly. Directly, older individuals are likely to assign higher values to project control and extra-organisational goals. Indirectly, age moderates the relationships by strengthening the levels of power distance and masculinity, both of which are likely to be associated with the assignation of higher levels of importance to project control and extra-organisational goals. Age also appears to affect the level of individualism, which is associated with lower levels of importance assigned to project control and extra-organisational goals.

The relationship between age and the perceived importance of project team management/development and intra-organisational goals was found to be insignificant.

\section{H3: Impact of Gender on Importance assigned to PSFFs}

Statistically significant differences were observed between men and women in the effects of all the cultural values on the PSFFs. The biggest differences between men and women occurred on the effects of masculinity and individualism. On project control and extra-organisational goals, the effects of both masculinity and individualism are larger for 
men than women. On project team management/development and intra-organisational goals, individualism has a stronger effect for women than men.

Another notable difference between men and women is that the effect of age on project control and extra-organisational goals is substantially larger for women than men.

\section{[Figure 2 and Figure 3 about here]}

\section{SEM Model Fit: Factorial Structure of Project Success/Failure Indicators (PSFIS)}

The path coefficients of the two factors on the PSFIs were all positive, lending support to the initial factorial configuration suggested by the exploratory factor analysis. The exception was 'quality'. As reported above, the path coefficient of project control and extra-organisational goals on 'quality' for women did not reach statistical significance. This contrasts with the model for men, where the coefficients of both PSFFs were positive and significant. As such, the SEM model appears to indicate a different factorial configuration of the PSFIs for women and men such that while men may perceive 'quality' a constituent of both PSFFs, for women it could be mostly a constituent of project team development and intra-organisational goals (factor 2).

To see how much of the importance attached to each PSFI can be explained by the SEM model, we inspected the R-squared value for each PSFI as shown in table VI. The SEM model accounts for from around $7 \%$ to around $38 \%$ of the variance of the importance attached to the PSFIs. Generally, the percentage of variance accounted for is slightly higher for men than women, which suggests that beyond cultural values, gender and age, other factors such as project context may be marginally more influential for women than men.

\section{[Table VI about here.]}




\section{Conclusions and Further Work}

Based on content analysis of interview transcripts of 40 project practitioners, we found that practitioners may assess projects using ten project success/failure indicators $(P S F I)$. Using Exploratory Factor Analysis $(E F A)$, we found that, rather than independent, the weights practitioners assign to the PSFIs are correlated so that the ten PSFIs can be reduced to two, more robust, project success/failure factors (PSFFs). Given its correlation with the PSFIs 'project scope', 'time', 'budget', 'client/sponsor brief', 'risk, safety and communication' and 'wider society/economy'; we interpreted factor 1 to be a representation of project control and extra-organisational goals; and factor 2 to be a representation of project team management/development and intra-organisational goals owing to its correlation with PSFIs 'business/organisational goals', 'the project team' and 'leadership and decision making'.

The EFA results imply that when practitioners weight PSFIs, rather than following a simple, one-dimensional view where all indicators can be unified into one factor à la Muller and Turner (2007) and Muller et al. (2012); the weighting of PSFIs is more consistent with the model of Shenhar et al. (2002) in that it is multi-dimensional. To begin to understand what this implies for project management practice, one may look at the two factors, in broad terms, as the two main orientations project practitioners may adopt when assessing projects. In this regard, factor one represents a task-focus and external outcomes orientation; an orientation which, it can be argued, is representative of the success factors used in earlier research by Pinto and Slevin (1987); factor two represents a people-focus, internal outcomes orientation, covering PSFls very similar to those used by Hoegl and Gemuenden (2001). In itself, each orientation seems like a natural way to assess success/failure but put together the two orientations are not without contrast: It is likely 
that the typical project practitioner will experience some uncertainty, even conflict, when attempting to weigh project control and extra-organisational goals (factor 1 ) alongside project team management/development and intra-organisational goals (factor 2). The weighting of quality could be particularly problematic. It appears to overlap the two factors.

Next, using structural equation modelling (SEM), we found support for our hypotheses that the levels individuals assign to the two factors are dependent on cultural values $(\mathrm{H} 1)$ as well as age $(\mathrm{H} 2)$ and gender $(\mathrm{H} 3)$. We believe these observed effects have practical implications for project management practice on the matching of practitioner cultural values to projects. We can also postulate the effects of differences in cultural values on decision performance within project teams.

The SEM results suggest that the effect of cultural values resolve down into two alternative managerial styles which each seem to be more suited to different kinds of project. Our results for $\mathrm{H} 1$ allow us to elaborate beyond what we said initially about these two styles. They show, for one thing, that our 'factor 1' managers, irrespective of gender, are more likely to possess masculine cultural values. Hofstede (Hofstede, 1980) describes masculine individuals as tough-minded, egotistical, materialistic, and prepared to resolve conflict through force rather than consensus. They prefer to work within fixed role structures and are not, as we suggested our factor 2 managers are, 'relationship oriented'. All of this supports our earlier interpretation of factor 1 managers as task-focussed traditional managers who rely heavily on those simpler and more traditional project measures that are used to greatest effect within structured and predictable project environments. These project managers can be viewed as experts who are very independent and autonomous when making the key decisions (Chasserio and Legault, 2010). 
Earlier, we interpreted factor 2 managers as perhaps being better suited to dealing with project novelty and ambiguity because of their greater use of social intelligence as a project skillset. This is supported by two of our SEM findings for H1. Firstly, it emerged that factor 1 managers tend to be individualists whereas factor 2 managers are more likely to be collectivists. Secondly, factor 2 managers score highly on uncertainty avoidance. Given that uncertainty avoidant managers are well known to seek risk reduction opportunities by engaging proactively, dynamically and strategically with complex and shifting environments (Schneider and De Meyer, 1991, Geletkanycz, 1997) it does indeed seem plausible that they constitute the best choice of manager for projects characterised by novelty and ambiguity.

What emerges from our study, then, is a dual typology of managerial styles which project planners perhaps ought to consider when matching ways of thinking about project success or failure to levels of project novelty and ambiguity. SEM findings for $\mathrm{H} 2$ (age) show that our factor 1 managers tend to be older, which is consistent with what we have said concerning their more traditional approach. Findings for $\mathrm{H} 3$ (gender) show that the factor 1 managerial style is strongly associated with male gender in particular. Yet, it appears that age has a stronger effect on factor 1 for women than men, which could very well be a reflection of the more pervasive effect of project environments on women that Cartwright and Gale (1995) allude to. All of this knowledge can help project planners ensure the right skillset is in place for the right project. Project planners can also use this knowledge to engender the cultural values that are appropriate for their project program, feasible, particularly, in predictable situations where similar projects are repeatedly conducted.

One of the greatest challenges in group-decision making processes is the selection and weighting of decision criteria (e.g. Davey and Olson, 1998). Our SEM results suggest that 
in heterogeneous environments, individuals are likely to assign weights to decision criteria (the PSFFs in broad terms or the PSFIs in specific terms) differently as a result of gender, age and cultural values. Such differences, possible at any point in the project lifecycle, could harm decision performance diversely: In project investment appraisal situations, disparate, unresolved differences in the view of the importance of criteria may lead to poor project choice. In on-going projects, unresolved differences in the view of the importance of criteria may lead to miss-aligned priorities and commitments. In operational, complete or even decommissioned projects, differences in view of success criteria may lead to misunderstandings about the level of progress or fulfilment of project objectives, which may explain, at least in part, difficulties in sustaining stakeholder confidence that Chen et al. (2009) found. It is critical then that project practitioners at all levels understand that such differences are likely and attempt to resolve them, for example by using structured group decision making techniques such as AHP or Delphi (see for example, Lai et al, 2002).

There is a potential upside: gender-, age- and culturally-variant weighting of criteria among individuals could create just the right level of debate (Elron, 1997), forcing project group decision makers to use multiple criteria. Conversely, homogeneous groups may be at risk of over-weighting some criteria while overlooking others, a scenario likely to cause use of non-compensatory and/or incomplete sets of decision criteria.

The foregoing discussion affirms what the literature (Hofstede, 1983a, Motwani et al., 2002, Salk and Brannen, 2000, Symkhovych, 2009) has often asserted: It is critical that project practitioners, particularly those operating globally, are competent in multi-cultural interactions. Our specific contribution to this body of research is that we have specified how knowledge of the cultural values may be used to match practitioners to levels of project 
novelty and ambiguity or what cultural values should be engendered in individuals to match these project characteristics. We have also suggested hypotheses on how differences in cultural values may impact on decision making performance in projects.

We see a number of ways this study can be extended. First: How important is expatriate status? On exploration of our sample of project practitioners, we found that a significant proportion of them were expatriates. Yet our primary research hypotheses do not directly examine the impact of expatriate status on perceptions of project success/failure. To begin to rectify this limitation, we tested a fourth, post-hoc hypothesis:

H4: There exist differences in the levels of importance practitioners assign to PSFIs due to expatriate status.

To examine if differences exist between expatriates and non-expatriates in the distribution of the levels of the importance they attach to each of the ten PSFIs, we conducted Wilcoxon-Mann-Whitney tests on each PSFI, setting expatriate status (= 0 if living in birth country, 1 otherwise) as the grouping variable. We used non-parametric tests because, as we reported earlier, the distributions of values on the PSFIs were significantly non-normal. The results, shown in table VII, partially support the hypothesis. There were statistically significant differences on four of the ten PSFIs; namely 'business/organisational goals', 'client/sponsor brief ', 'leadership and decision making' and 'quality'. These results indicate that expatriate status may indeed be important in how practitioners perceive project success. A more thorough examination of its impact in project management would be valuable. It would be interesting, for example, to explore whether managers who have been working abroad for a significant amount of time do actually switch their cultural orientation (Friedman et al., 2012). With increasing globalisation and the increased 
potential for multicultural projects it would be interesting to measure a project manager's ability to adapt to the business environment and changing circumstances.

\section{[Table VII about here]}

Second, though, as we said earlier, they appear intuitive, our findings beg many separate questions concerning why either factor 1 or factor 2 managerial styles should arise within specific cultural contexts. We suggest that longstanding psychology literature on task versus people focus might well help shed further light on these different styles at the individual level. Sociological and cultural literatures dealing with the global intergenerational shift from materialist to post-materialist value orientation might also provide a viable framework for exploring our two managerial styles within the broader context of global cultural change.

Third, we have explored the likely effects on decision making performance as a result of the individual differences (gender, age, cultural values) in importance attached to PSFFs. The next step would be to test if these effects do indeed occur.

Finally, research shows that contexts such as in-group or out-group situations can moderate the effects of the cultural values on outcomes; and effects observable at individual level can be absent or contrary at group level (Kirkman et al., 2006, Oyserman et al., 2002). Similarly, project complexity has been shown to moderate the effect of leadership on project performance (Muller et al., 2012). Thus, it would be of great benefit to project management practice to examine if group characteristics such as degree of cultural heterogeneity (cultural distance) and project complexity do moderate the effects of the cultural values we have reported.

\section{References}


Au, K.Y. (1999), 'Intra-Cultural Variation: Evidence and Implications for International Business', Journal of International Business Studies, Vol. 30, No. 4, pp. 799-812.

Bendoly, E., Perry-Smith, J. and And Bachrach, D. (2010), 'The perception of difficulty in project-work planning and its impact on resource sharing', Journal of Operations Management, Vol. 28, No. 5, pp. 385-397.

Bresnen, M., Goussevskaia, A. and Swan, J. (2004), 'Embedding New Management Knowledge in Project-Based Organizations', Organization Studies, Vol. 25, No. 9, pp. 1535-1555.

Browne, M.W. (1984), 'Asymptotically distribution-free methods for the analysis of covariance structures', British Journal of Mathematical and Statistical Psychology, Vol. 37, pp. 62-83.

Bryde, D.J. (2003), 'Project management concepts, methods and application', International Journal of Operations \& Production Management, Vol. 23, No. 7, pp. 775-793.

Burnes, B. and James, H. (1995), 'Culture, cognitive dissonance and the management of change', International Journal of Operations \& Production Management, Vol. 15, No. 8, pp. 14-33.

Byrne, B.M. (2010), Structural Equation Modelling with AMOS, Hove: Rotledge.

Cagliano, R., Caniato, F., Golini, R., Longoni, A. and Micelotta, A. (2011), 'The impact of country culture on the adoption of new forms of work organization', International Journal of Operations \& Production Management, Vol. 31 No. 3 pp. 297-323

Cartwright, S. and Gale, A. (1995), 'Project management: different gender, different culture?: A discussion on gender and organizational culture - part 2', Leadership \& Organization Development Journal, Vol. 16, No. 4, pp. 12-16.

Castles, S. (2000), 'International Migration at the Beginining of the Twenty-First Century: Global Trends and Issues', International Social Science Journal, Vol. 52, No. 165, pp. 269-281.

Cavusgil, S. and Das, A. (1997), 'Methodological Issues in Empirical Cross-Cultural Research: A Survey of the Management Literature and a Framework', Management International Review, Vol. 37, No. 1, pp. 71-96.

Chasserio, S. and Legault, M.-J. (2010), 'Discretionary Power of Project Managers in Knowledge Intensive Firms and Gender Issues', Canadian Journal of Administrative Sciences Vol. 27, No. 3, pp. 236-248.

Chen, C.C., Law, C. and Yang, S.C. (2009), 'Managing ERP Implementation Failure: A Project Management Perspective', IEEE Transactions on Engineering Management, Vol. 56, No. 1, pp. 157-170.

Chevrier, S. (2003), 'Cross-cultural management in multinational project groups', Journal of World Business, Vol. 38, No. 2, pp. 141-149.

Childe, S.J. (2011), 'What are the hot topics in the management of operations?', Production Planning \& Control, Vol. 22, No. 7, pp. 611-611. 
Chipulu, M., Neoh, J.G., Ojiako, U. and Williams, T. (2012), 'A Multidimensional Analysis of Project Manager Competences', IEEE Transactions on Engineering Management, Vol. In print.

Davey, A. and Olson, D. (1998), 'Multiple Criteria Decision Making Models in Group Decision Support', Group Decision and Negotiation, Vol. 7, No. 1, pp. 55-75.

Dillman, D.A. (2007), Mail and Internet Surveys - the Tailored Design Method 2007 (Update with New Inernet, Visual and Mixed Modes Guide) New York: Wiley.

Eckhardt, G. (2002), 'Culture's Consequences: Comparing values, behaviors, institutions and organisations across nations', Australian Journal of Management, Vol. 27, No. 1, pp. 89-95.

Edwards, A.L. (1997), Techniques of Attitude Scale Construction, New York: Irvington Publishers.

Elron, E. (1997), 'Top management teams within multinational corporations: Effects of cultural heterogeneity', The Leadership Quarterly, Vol. 8, No. 4, pp. 393-412.

Fang, T. (2003), 'A Critique of Hofstede's Fifth National Culture Dimension', International Journal of Cross Cultural Management, Vol. 3, No. 3, pp. 347-368.

Fernández, D.R., Carlson, D.S., Stepina, L.P. and Nicholson, J.D. (1997), 'Hofstede's Country Classification 25 years later', Journal of Social Psychology, Vol. 137, No. 1, pp. 43-54.

Fowler, A. and Walsh, M. (1999), 'Conflicting perceptions of success in an information systems project', International Journal of Project Management, Vol. 17, No. 1, pp. 110.

Friedman, R., Liu, W., Chi, S.-C.S., Hong, Y.-Y. and Sung, L.-K. (2012), 'Cross-Cultural Management and Bicultural Identity Integration: When does Experience Abroad Lead to Appropriate Cultural Switching? ', International Journal of Intercultural Relations, Vol. 36 pp. 130-139.

Gelbard, R. and Carmeli, A. (2009), 'The interactive effect of team dynamics and organizational support on ICT project success', International Journal of Project Management, Vol. 27, No. 5, pp. 464-470.

Geletkanycz, M.A. (1997), 'The salience of 'culture's consequences': the effects of cultural values on top executive commitment to the status quo', Strategic Management Journal, Vol. 18, No. 8, pp. 615-634.

Harris, P.R. (2004), 'European leadership in cultural synergy', European Business Review, Vol. 16, No. 4, pp. 358-380.

Henderson, L.S. and Stackman, R.W. (2010), 'An exploratory study of gender in project management: Interrelationships with role, location, technology, and project cost', Project Management Journal, Vol. 41, No. 5, pp. 37-55.

Hobday, M. (2000), 'The project-based organisation: an ideal form for managing complex products and systems? ', Research Policy, Vol. 29, No. 7-8, pp. 871-893.

Hoegl, M. and Gemuenden, H.G. (2001), 'Teamwork Quality and the Success of Innovative Projects: A Theoretical Concept and Empirical Evidence', Organization Science, Vol. 12 , No. 4, pp. 435-449. 
Hofstede, G. (1980), Culture's Consequences: International Differences in Work Related Values, Bervely Hills, CA Sage.

Hofstede, G. (1983a), 'Cultural Dimensions for Project Management ', International Journal of Project Management, Vol. 1, No. 1, pp. 4-48.

Hofstede, G. (1983b), 'National Cultures Revisited', Behaviour Science Research, , Vol. 18, No. 4 pp. 285-305.

Hofstede, G. (2001), Culture's Consequences: Comparing values, behaviours, institutions and organisations accross nations: Sage.

Hofstede, G. and Bond, M.H. (1984), 'Hofstede's Culture Dimensions: An Independent Validation Using Rokeach's Value Survey ', Journal of Cross-Cultural Psychology., Vol. 15, No. 4, pp. 417-433.

Hofstede, G. and Bond, M.H. (1988), 'The Confucius connection: From cultural roots to economic growth', Organizational Dynamics, Vol. 16, No. 4, pp. 5-21.

House, R.J., Hanges, P.J., Javidan, M., Dorfman, P.W. and Gupta, V. (eds.), Culture, Leadership and Organizations : The GLOBE Study of 62 Societies: Thousand Oaks CA, Sage.

Jugdev, K. and Müller, R. (2005), 'A reptrospective look at our evolving understanding of project success', Project Management Journal, Vol. 36, No. 4, pp. 19-34.

Kealey, D.J., Protheroe, D.R., Macdonald, D. and Vulpe, T. (2005), 'Re-examining the Role of Training in Contributing to International Project Success: A Literature Review and an Outline of a New Model Training Program', International Journal of Intercultural Relations Vol. 29 pp. 289-316.

Keil, M., Wallace, L., Turk, D., Dixon-Randall, G. and Nulden, U. (2000), 'An Investigation of Risk Perception and Risk Propensity on the Decision to Continue a Software Development Project', The Journal of Systems and Software, Vol. 53, No. 3, pp. 145157.

Kirkman, B.L., Lowe, K.B. and Gibson, C.B. (2006), 'A quarter century of Culture's Consequences: a review of empirical research incorporating Hofstede's cultural values framework', J Int Bus Stud, Vol. 37, No. 3, pp. 285-320.

Lai, V.S., Wong, B.K. and Cheung, W. (2002), 'Group decision making in a multiple criteria environment: A case using the AHP in software selection', European Journal of Operational Research, Vol. 137, No. 1, pp. 134-144.

Lenartowicz, T. and Roth, K. (1999), 'A Framework for Culture Assessment', Journal of International Business Studies, Vol. 30, No. 4, pp. 781-798.

Loosemore, M. and Lee, P. (2002), 'Communication problems with ethnic minorities in the construction industry', International Journal of Project Management, Vol. 20, pp. 517-524.

Mahroum, S. (2000), 'Highly skilled globetrotters: mapping the international migration of human capital', R\&D Management, Vol. 30, No. 1, pp. 23-32. 
Mcsweeney, B. (2002), 'Hofstede's model of national cultural differences and their consequences: A triumph of faith - a failure of analysis ', Human Relations, Vol. 55, No. 1, pp. 89-118.

Mendez, A. (2003), 'The coordination of globalized R\&D activities through project teams organization: an exploratory empirical study', Journal of World Business, Vol. 38, No. 2, pp. 96-109.

Miller, D.M., Fields, R., Kumar, A. and Ortiz, R. (2000), 'Leadership and Organizational Vision in Managing a Multiethnic and Multicultural Project Team ', Journal of Management in Engineering, Vol. 16, No. 6, pp. 18-22.

Motwani, J., Mirchandani, D., Madan, M. and Gunasekaran, A. (2002), 'Successful implementation of ERP projects: Evidence from two case studies', International Journal of Production Economics, Vol. 75, No. 1-2, pp. 83-96.

Muller, R., Geraldi, J. and Turner, J.R. (2012), 'Relationships Between Leadership and Success in Different Types of Project Complexities', IEEE Transactions in Engineering Management, Vol. 59, No. 1, pp. 77-90.

Muller, R. and Turner, J.R. (2007), 'Matching the project manager's leadership style to project type', International Journal of Project Management Vol. 25, pp. 21-32.

Newman, K.L. and Nollen, S.D. (1996), 'Culture and Congruence: The Fit between Management Practices and National Culture', Journal of International Business Studies, Vol. 27, No. 4, pp. 753-779.

Nisbett, R.E. and Miyamoto, Y. (2005), 'The influence of culture: holistic versus analytic perception', Trends Cogn Sci, Vol. 9, No. 10, pp. 467-73.

Oyserman, D., Coon, H.M. and Kemmelmeier, M. (2002), 'Rethinking individualism and collectivism: evaluation of theoretical assumptions and meta-analyses', Psychol Bull, Vol. 128, No. 1, pp. 3-72.

Pagell, M., Katz, J.P. and Sheu, C. (2005), 'The importance of national culture in operations management research', International Journal of Operations \& Production Management, Vol. 25, No. 4, pp. 371-394.

Pasche, M., Persson, M. and Löfsten, H. (2011), 'Effects of platforms on new product development projects', International Journal of Operations \& Production Management, Vol. 31, No. 11, pp. 1144-1163.

Pereira, J., Cerpa, N., Verner, J., Rivas, M. and Procaccino, J. (2008), 'What do software practitioners really think about project success: A cross-cultural comparison ', The Journal of Systems and Software Vol. 81, pp. 897-907.

Pinto, J.K. and Kharbanda, O.P. (1995), 'Lessons for an accidental profession', Business Horizons Vol. 38 No. 2, pp. 41-51.

Pinto, J.K. and Prescott, J.E. (1988), 'Variations in critical success over the stages in the project life cycle ', Journal of Management, Vol. 14, pp. 5-18.

Pinto, J.K. and Slevin, D.P. (1987), 'Critical Factors in Successful Project Implementation', IEEE Transactions on Engineering Management, Vol. 34, No. 1, pp. 22-27. 
Prajogo, D.I. and Mcdermott, C.M. (2011), 'The relationship between multidimensional organizational culture and performance', International Journal of Operations \& Production Management, Vol. 31, No. 7-8, pp. 712-735.

Prasad, S. and Babbar, S. (2000), 'International operations management research', Journal of Operations Management Vol. 18, pp. 209-247.

Ramburuth, P. and Mccormick, J. (2001), 'Learning diversity in higher education: A comparative study of Asian international and Australian students', Higher Education, Vol. 42, No. 3, pp. 333-350.

Rokeach, M. (1973), The nature of human values, NY: Free Press.

Rubin, I. and Seeling, W. (1967), 'Experience as a factor in the selection and performance of project managers', IEEE Transactions on Engineering Management, Vol. 14, pp. 131134.

Salk, J.E. and Brannen, M.Y. (2000), 'National Culture, Networks, and Individual Influence in a Multinational Management Team', The Academy of Management Journal, Vol. 43, No. 2, pp. 191-202.

Schneider, S.C. and De Meyer, A. (1991), 'Interpreting and responding to strategic issues: The impact of national culture', Strategic Management Journal, Vol. 12, No. 4, pp. 307-320.

Schwartz, S.H. (1994a), 'Are There Universal Aspects in the Structure and Contents of Human Values?', Journal of Social Issues, Vol. 50, No. 4, pp. 19-45.

Schwartz, S.H. (1994b), 'Beyond individualism/collectivism: New cultural dimensions of values', IN, Kim, U., Triandis, H.C., Kagitcibasi, C., Choi, S., Yoon, S. and Yoon, G. (eds.), Individualism and collectivism: Theory, method and applications, Thousands Oaks, CA: Sage.

Scott-Young, C. and Samson, D. (2008), ' Project success and project team management: Evidence from capital projects in the process industries ', Journal of Operations Management, Vol. 26, No. 6, pp. 749-766.

Shenhar, A., Dvir, D., Levy, O. and Maltz, A. (2001), 'Project success: a multidimensional strategic concept ', Long Range Planning, Vol. 34, No. 6, pp. 699-725.

Shenhar, A.J., Tishler, A., Dvir, D., Lipovetsky, S. and Lechler, T. (2002), 'Refining the search for project success factors: a multivariate, typological approach', R\&D Management, Vol. 32, No. 2, pp. 111-126.

Sivakumar, K. and Nakata, C. (2001), 'The Stampede toward Hofstede's Framework: Avoiding the Sample Design Pit in Cross-Cultural Research', Journal of International Business Studies, Vol. 32, No. 3, pp. 555-574.

Søndergaard, M. (1994), 'Research Note: Hofstede's Consequences: A Study of Reviews, Citations and Replications', Organization Studies, Vol. 15, No. 3, pp. 447-456.

Stull, J.B. and Von Till, B. (1994), 'Determinants of Ethnocentrism: A Study of Relationship between Students' Exposure to Other Cultures and their Attitudes toward Cultural Values', Annual Meeting of the Western States Communication Association, San Jose, CA: Western States Communication Association. 
Symkhovych, D. (2009), 'The Relationship between Intercultural Effectiveness and Perceived Project Team Performance in the Context of International Development', International Journal of Intercultural Relations, Vol. 33, pp. 383-390.

Taras, V., Kirkman, B.L. and Steel, P. (2010), 'Examining the impact of Culture's consequences: a three-decade, multilevel, meta-analytic review of Hofstede's cultural value dimensions', Journal of Applied Psychology, Vol. 95, No. 3, pp. 405-39.

Thomas, G. and Fernández, W. (2008), 'Success in IT projects: A matter of definition?', International Journal of Project Management, Vol. 26, No. 7, pp. 733-742.

Triandis, H.C. (1979), 'Values, attitudes, and interpersonal behavior', Nebraska Symposium on Motivation Vol. 27, pp. 195-259.

Varnum, M.E.W., Grossmann, I., Kitayama, S. and Nisbett, R.E. (2010), 'The Origin of Cultural Differences in Cognition', Current Directions in Psychological Science, Vol. 19, No. 1, pp. 9-13.

Walker, H. and Brammer, S. (2009), 'Sustainable procurement in the United Kingdom public sector', Supply Chain Management: An International Journal, Vol. 14, No. 2, pp. 128137.

Weber, E.U. and Hsee, C. (1998), 'Cross-Cultural Differences in Risk Perception, but CrossCultural Similarities in Attitudes towards Perceived Risk', Management Science, Vol. 44, No. 9, pp. 1205-1217.

Wiengarten, F., Fynes, B., Pagell, M. and De Búrca, S. (2011), 'Exploring the impact of national culture on investments in manufacturing practices and performance: An empirical multi-country study', International Journal of Operations \& Production Management, Vol. 31, No. 5, pp. 554-578

Winch, G., Millar, C. and Clifton, N. (1997), 'Culture and Organization: The Case of Transmanche-Link', British Journal of Management, Vol. 8, No. 3, pp. 237-249.

Zwikael, O. and Ahn, M. (2011), 'The Effectiveness of Risk Management: An Analysis of Project Risk Planning Across Industries and Countries', Risk Analysis, Vol. 31, No. 1, pp. 25-37.

Zwikael, O., Shimizu, K. and Globerson, S. (2005), 'Cultural differences in project management capabilities: A field study', International Journal of Project Management, Vol. 23, No. 6, pp. 454-462. 


\section{Table I Main Interview Framework}

\section{Question \\ What are the determinants of success and failure and how are they ranked and related?}

Is project success and failure gradable?

When are perceptions of success and failure formed and do they change with time? When can a final 'reliable' or 'stable' perception be formed?

Do different stakeholders form different perceptions? (sponsor CEO, CIO, CFO, programme director, project manager, contactor, end user, consultant, member of the public, etc.

\section{Rationale}

For example, can high success in one factor compensate for failure in another factor so that the overall perception is project success? These factors would include the traditional measures, time, cost, quality, scope, safety, but can also include many more dynamic and flexible measures. They can also include reference to technical and business performance measures. For example, are some projects extremely successful, while others are just slightly successful? In other words, is project success and failure a fuzzy concept?

This question relates to stages in the project life cycle. This question can be followed up by with prompting for examples from the interviewees' experiences.

Perceptions may differ between different types of stakeholder. The interviewee should be encouraged to express their free (i.e. with little or no prompting) views on projects.

T able II: Project Success/Failure Indicators Identified from Interviews

\begin{tabular}{|c|c|c|c|}
\hline $\begin{array}{l}\text { Short Description } \\
\text { of Indicator }\end{array}$ & Longer Description of Indicator & $\begin{array}{l}\text { Example of 'Success' under this } \\
\text { Indicator }\end{array}$ & $\begin{array}{l}\text { Example of 'Failure' under this } \\
\text { Indicator }\end{array}$ \\
\hline $\begin{array}{l}\text { Client/Sponsor } \\
\text { Brief }\end{array}$ & $\begin{array}{l}\text { Achievement of intended } \\
\text { outcomes as defined by the } \\
\text { sponsor/owner/client. }\end{array}$ & $\begin{array}{l}\text { The project achieved all its } \\
\text { intended outcomes as defined } \\
\text { by the sponsor/owner/client. }\end{array}$ & $\begin{array}{l}\text { The project achieved none of its } \\
\text { intended outcomes as defined } \\
\text { by the sponsor/owner/client. }\end{array}$ \\
\hline Bus/Org Goals & Contribution to business goals. & $\begin{array}{l}\text { The project made a significant } \\
\text { and valuable contribution to } \\
\text { business goals. }\end{array}$ & $\begin{array}{l}\text { The project made no } \\
\text { contribution to business goals. }\end{array}$ \\
\hline $\begin{array}{l}\text { Wider } \\
\text { Society/Economy }\end{array}$ & $\begin{array}{l}\text { Contribution to } \\
\text { society/community/economy. }\end{array}$ & $\begin{array}{l}\text { The project made a significant } \\
\text { and valuable contribution to } \\
\text { society/community/economy. }\end{array}$ & $\begin{array}{l}\text { The project made no } \\
\text { contribution to } \\
\text { society/community/economy. }\end{array}$ \\
\hline Project Scope & $\begin{array}{l}\text { Planned and approved project } \\
\text { scope (including any approved } \\
\text { changes). }\end{array}$ & $\begin{array}{l}\text { The project was completed } \\
\text { within scope. }\end{array}$ & $\begin{array}{l}\text { The project was completed } \\
\text { significantly under or over } \\
\text { scope. }\end{array}$ \\
\hline Budget & $\begin{array}{l}\text { Planned and approved budget } \\
\text { (including any approved } \\
\text { changes) }\end{array}$ & $\begin{array}{l}\text { The project was completed } \\
\text { under or on budget. }\end{array}$ & $\begin{array}{l}\text { The project was completed } \\
\text { significantly over budget. }\end{array}$ \\
\hline Time & $\begin{array}{l}\text { Planned and approved project } \\
\text { time (including any approved } \\
\text { changes). }\end{array}$ & $\begin{array}{l}\text { The project was completed } \\
\text { within or on time. }\end{array}$ & $\begin{array}{l}\text { The project was completed } \\
\text { significantly late. }\end{array}$ \\
\hline Quality & $\begin{array}{l}\text { Planned and approved quality } \\
\text { and performance criteria. }\end{array}$ & $\begin{array}{l}\text { The project met or exceeded all } \\
\text { quality and performance } \\
\text { criteria. }\end{array}$ & $\begin{array}{l}\text { Some or all of the project's } \\
\text { quality or performance criteria } \\
\text { were not met. }\end{array}$ \\
\hline $\begin{array}{l}\text { Risk, Safety and } \\
\text { Communication }\end{array}$ & $\begin{array}{l}\text { Communications, risk and } \\
\text { safety management. }\end{array}$ & $\begin{array}{l}\text { The communications, risk and } \\
\text { safety were effectively } \\
\text { managed. }\end{array}$ & $\begin{array}{l}\text { Communications, risk and safety } \\
\text { were poorly managed. }\end{array}$ \\
\hline $\begin{array}{l}\text { Lead/ship \& Dec. } \\
\text { Making }\end{array}$ & $\begin{array}{l}\text { Project leadership and decision } \\
\text { making }\end{array}$ & $\begin{array}{l}\text { Most stakeholders agree that } \\
\text { project leadership and decision } \\
\text { making were appropriate and } \\
\text { effective. }\end{array}$ & $\begin{array}{l}\text { Most stakeholders agree that } \\
\text { project leadership and decision } \\
\text { making were neither } \\
\text { appropriate nor effective. }\end{array}$ \\
\hline The project team & The project team & $\begin{array}{l}\text { The project team worked } \\
\text { effectively and lessons were } \\
\text { learned for future projects. }\end{array}$ & $\begin{array}{l}\text { The project team did not work } \\
\text { effectively and lessons were not } \\
\text { learned for future projects }\end{array}$ \\
\hline
\end{tabular}


T able III: Standardised Country means: Cultural Values Based on Hofstede Dimensions

\begin{tabular}{llllll}
\hline Country & $\begin{array}{l}\text { Number of } \\
\text { Respondents }\end{array}$ & $\begin{array}{l}\text { Individualism } \\
\text { (alpha = 0.69) }\end{array}$ & $\begin{array}{l}\text { Masculinity } \\
\text { (alpha = 0.59) }\end{array}$ & $\begin{array}{l}\text { Power } \\
\text { Distance } \\
\text { (alpha = 0.73) }\end{array}$ & $\begin{array}{l}\text { Uncertainty } \\
\text { Avoidance } \\
\text { (alpha = 0.64) }\end{array}$ \\
\hline Brazil & 204 & -0.5 & 0.3 & 0.72 & 0.69 \\
China & 201 & -0.28 & -0.33 & -0.82 & -0.24 \\
Greece & 273 & -0.94 & 0.29 & 0.07 & -0.66 \\
\hline Nigeria & 124 & 0.23 & -0.83 & -0.69 & -0.46 \\
Other Countries & 55 & -1.01 & 0.49 & 0.94 & 1.07 \\
Thailand & 36 & 0.43 & -0.69 & -0.72 & -0.48 \\
United Arab Emirates & 106 & -1.15 & 1.01 & 1.26 & 1.31 \\
\hline United Kingdom & 211 & 0.34 & -0.48 & -0.61 & -0.42 \\
United States & 45 & 0.93 & 0.58 & 1.27 & 1.15 \\
\hline
\end{tabular}

T able IV: Distribution of Primary Project Roles

\begin{tabular}{|c|c|c|c|c|c|}
\hline Project Role & Frequency & Percent & Project Role & Frequency & Percent \\
\hline Project Consultant & 161 & 13 & $\begin{array}{l}\text { Little Or No Experience Of } \\
\text { Project Management }\end{array}$ & 145 & 12 \\
\hline Project Director & 129 & 10 & Project Assistant & 2 & $<1$ \\
\hline Member Of The Public & 82 & 7 & $\begin{array}{l}\text { Steering Committee Or } \\
\text { Project Board Member }\end{array}$ & 44 & 4 \\
\hline Project End User & 91 & 7 & Project Support & 158 & 13 \\
\hline $\begin{array}{l}\text { Project Sponsor, Client or } \\
\text { Customer }\end{array}$ & 44 & 4 & Other (Role not specified) & 17 & 1 \\
\hline Project Manager & 362 & 29 & & & \\
\hline
\end{tabular}

Table V: Factor loadings of PSFIs after Varimax rotation

\begin{tabular}{|c|c|c|c|}
\hline Variable (PSFI) & Description of PSFI & $\begin{array}{l}\text { Factor } 1 \\
\text { (PSFF 1) }\end{array}$ & $\begin{array}{l}\text { Factor } 2 \\
\text { (PSFF 2) }\end{array}$ \\
\hline Budget & $\begin{array}{l}\text { Planned and approved budget (including any approved } \\
\text { changes) }\end{array}$ & .740 & .233 \\
\hline Bus/Org Goals & Contribution to business goals. & .203 & .592 \\
\hline Client/Sponsor Brief & $\begin{array}{l}\text { Achievement of intended outcomes as defined by the } \\
\text { sponsor/owner/client. }\end{array}$ & .688 & .169 \\
\hline $\begin{array}{l}\text { Risk, Safety and } \\
\text { Communication }\end{array}$ & Communications, risk and safety management. & 607 & .308 \\
\hline Lead/ship \& Dec. Making & Project leadership and decision making & .147 & .791 \\
\hline Quality & Planned and approved quality and performance criteria. & .354 & .589 \\
\hline Project Scope & $\begin{array}{l}\text { Planned and approved project scope (including any } \\
\text { approved changes). }\end{array}$ & .777 & .172 \\
\hline Wider Society/Economy & Contribution to society/community/economy. & .525 & .194 \\
\hline Time & $\begin{array}{l}\text { Planned and approved project time (including any } \\
\text { approved changes). }\end{array}$ & .774 & .160 \\
\hline
\end{tabular}


T able VI: Amount of Variance of each PSFIs explained by the SEM

\begin{tabular}{|l|l|l|}
\hline Project success and/or failure indicator (PSFI) & \multicolumn{2}{|c|}{ R-square Values } \\
\cline { 2 - 3 } & Females & Males \\
\hline Budget & 0.116 & 0.18 \\
\hline Bus/Org Goals & 0.168 & 0.226 \\
\hline Client/Sponsor Brief & 0.385 & 0.136 \\
\hline Risk, Safety and Communication & 0.079 & 0.26 \\
\hline Lead/ship \& Dec. Making & 0.129 & 0.086 \\
\hline Quality & 0.11 & 0.127 \\
\hline Project Scope & 0.156 & 0.26 \\
\hline Wider Society/Economy & 0.199 & 0.127 \\
\hline Time & 0.087 & 0.332 \\
\hline The project team & 0.09 & 0.075 \\
\hline
\end{tabular}

Figure 1 Scree Plot: Dimensionality of PSFIs

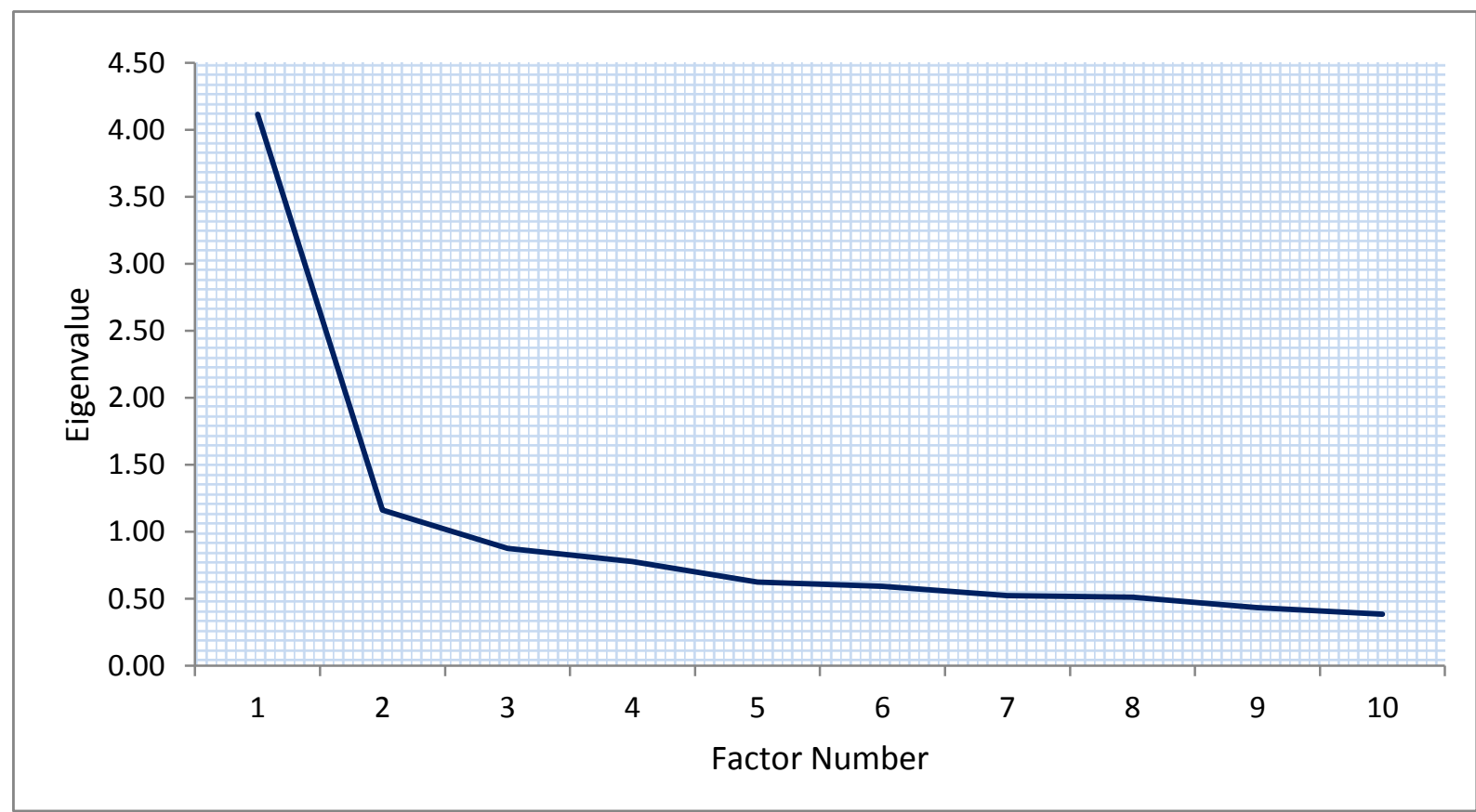


Figure 2: SEM Standardised Path Coefficients for Females

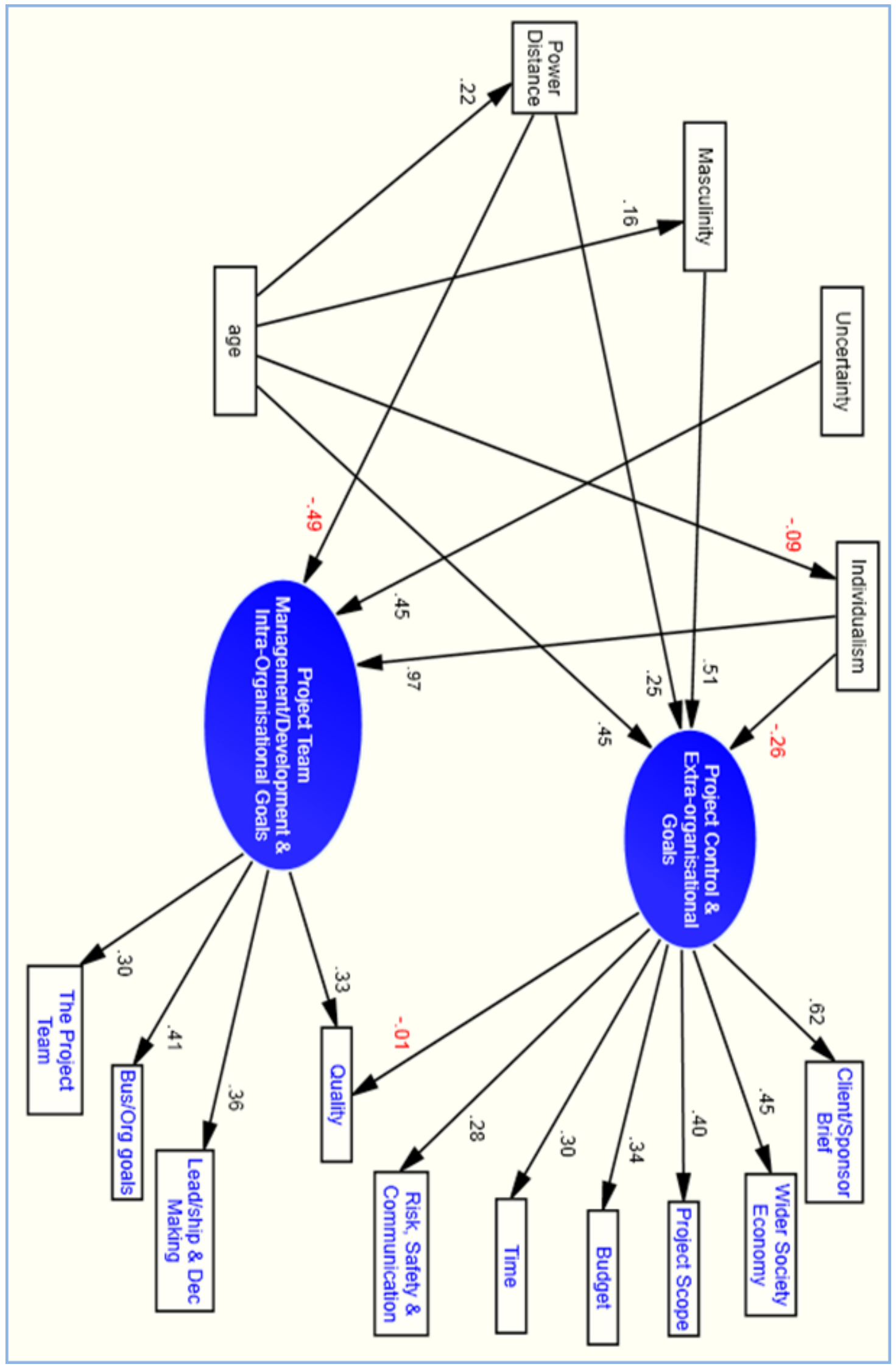


Figure 3: SEM Standardised Path Coefficients for Males

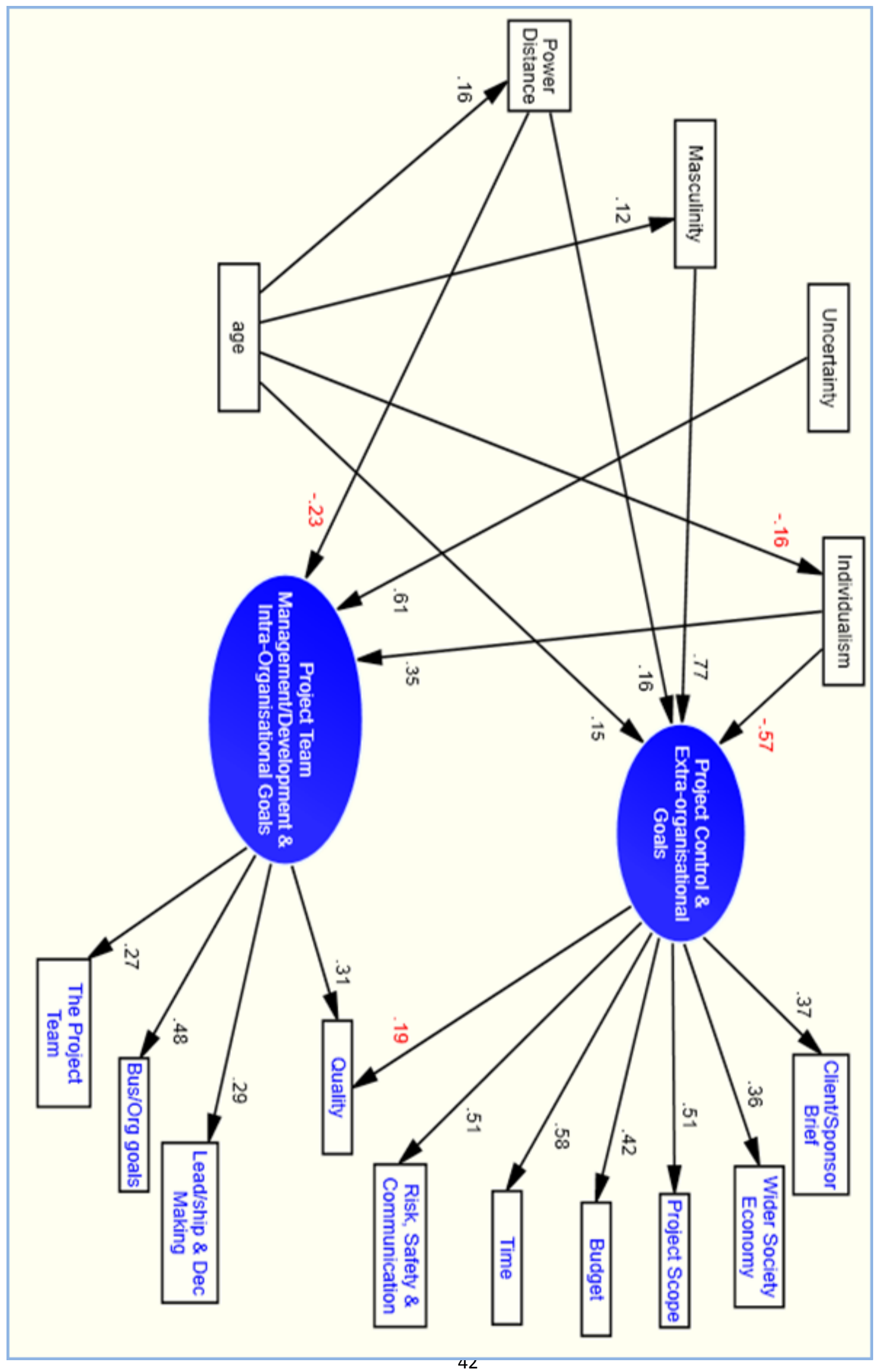


Table VII: Differences in Distributions of Importance Ratings of PSFIs by Expatriate Status

\begin{tabular}{|l|c|c|c|c|}
\hline $\begin{array}{l}\text { Project success and/or failure } \\
\text { indicator (PSFI) }\end{array}$ & $\begin{array}{l}\text { Mann- } \\
\text { Whitney U }\end{array}$ & Wilcoxon W & Z & $\begin{array}{l}\text { P-value (2- } \\
\text { tailed) }\end{array}$ \\
\hline Budget & 127608.5 & 166668.5 & -1.784 & 0.074 \\
\hline Bus/Org Goals & 120406 & 597182 & $-3.264^{* *}$ & 0.001 \\
\hline Client/Sponsor Brief & 110291.5 & 149351.5 & $-5.44^{* *}$ & 0.000 \\
\hline Risk, Safety and Communication & 135401 & 174461 & -0.16 & 0.873 \\
\hline Lead/ship \& Dec. Making & 120999 & 597775 & $-3.105^{* *}$ & 0.002 \\
\hline Quality & 123243.5 & 600019.5 & $-2.661^{* *}$ & 0.008 \\
\hline Project Scope & 120973 & 160033 & $-3.138^{* *}$ & 0.002 \\
\hline Wider Society/Economy & 131357 & 170417 & -0.971 & 0.332 \\
\hline Time & 129277.5 & 168337.5 & -1.443 & 0.149 \\
\hline The project team & 131894 & 608670 & -0.855 & 0.392 \\
\hline $\begin{array}{l}\text { Grouping Variable: 0 if living in birth country, 1 otherwise } \\
* * \text { Z is significant at the 0.01 p-value level }\end{array}$ & & \\
\hline
\end{tabular}

